\title{
Charles Lienhard at 70
}

\author{
Nico Schneider ${ }^{1}$, John Hollier ${ }^{2}$ \\ 1 79, rue Tony-Dutreux, L-1429 Luxembourg \\ 2 Muséum d'histoire naturelle de Genève, C.P. 6434, CH1211 Genève 6, Switzerland \\ http://zoobank.org/94116E78-970A-489A-BD8A-C54911BEB171
}

Corresponding author: John Hollier (john.hollier@ville-ge.ch

Received 26 September 2018

Accepted 17 October 2018

Published 20 November 2018

Charles Lienhard was born in Zurich on 15 January 1949. The spelling of his first name was chosen in honour of his paternal grandfather Karl Lienhard, who emigrated from Zurich to France at the beginning of the $20^{\text {th }}$ century. After a traditional high-school education, including the study of Latin and Ancient Greek, he turned to the natural sciences in 1967, enrolling in the biology course at the Swiss Federal Institute of Technology (Eidgenössische Technische Hochschule, ETH Zurich). Fascinated by the world of insects, and greatly encouraged by Willi Sauter, professor of systematic entomology, he completed his Master's degree with a faunistic study of the Psocoptera (psocids, or barklice and booklice) of the Zurich region in 1972 . He joined the Swiss Entomological Society in the same year. After accepting Sauter's suggestion of psocids as a subject, he was surprised to discover that even professional entomologists barely knew this group of fragile but charming insects, which are omnipresent in Swiss forests although their common name in German (Staubläuse) might lead one to expect them only in kitchen cupboards. Lienhard then began a doctorate at the ETH Institute of Entomology, investigating the Psocoptera fauna of the Swiss National Park in Engadin under the supervision of professors Georg Benz and Willi Sauter, a study which was awarded the ETH silver medal in 1977.

From 1976 to 1979 Lienhard was part of a team of biologists studying an alpine grassland ecosystem in the Swiss National Park. He was responsible for the Collembola, which are an extremely diverse group in this habitat (from which psocids are almost entirely absent). In parallel with this study of the community ecology of the soil fauna, Lienhard continued to collect psocids during many trips to the Mediterranean region, accompanied from 1977 by his wife Heidi. She soon came to share his enthusiasm for these small and delicate insects, a group often overlooked despite being easy to collect using simple classical methods (Lienhard et al. 1987), and it was Heidi who sewed the linings of the early modified-um- brella beating trays that he always used in the field. He became an accomplished field entomologist, whose calm and adaptable approach to fieldwork made him a highly valued travelling companion. Lienhard is in many ways a traditional naturalist, interested in the biology and ecology of the species he studies, and was successful in rearing many psocid species, including some for which adults of one sex were previously unknown.

In the course of his Collembola research, Lienhard came into contact with Bernd Hauser, then curator of the Department of Arthropods at the Natural History Museum of Geneva (Lienhard et al. 2016) and responsible for the largest collection of Collembola in Switzerland. Following a fruitful collaboration Lienhard was recruited by Hauser as a research officer in the Department of Arthropods in 1981. When Hauser retired, Lienhard acted as interim curator for a year before resuming his role as research officer under the new curator, Peter Schwendinger in 1999. His role at the museum also involved collaboration with the curator for public outreach, exhibition and educational activities, as well as management of the scientific collections. He participated in many excursions and expeditions organised by Hauser, mainly in the West Palaearctic but including South East Asia, Madagascar and North America. These add up to almost a year of travelling together, and provide Bernd Hauser with some fond memories, not only of the pleasures of the chase but of the opportunity to spend time with a cultured and thoughtful man. It was with Hauser, a noted biospeleologist, that Lienhard first studied the fauna of caves, which later became such a fruitful aspect of his research.

Among Lienhard's most interesting discoveries are the first Old World representatives of the families Troctopsocidae and Protroctopsocidae (six new genera, three from Europe and three from South East Asia), and his contributions to our knowledge of the family Prionoglaridae (five new genera, one from South East Asia, two from southern Africa and two from South America). 
Alongside his research, he was editor of the Revue suisse de Zoologie, published by the Museum and the Swiss Zoological Society from 1998 to 2005, and of the series Nationalpark-Forschung in der Schweiz published by the Scientific Commission of the Swiss National Park from 1989 to 1999. He organised the Second International Workshop on Psocoptera in Geneva in 1996, bringing together experts from five continents; many were already, or would become, friends. Thanks to Lienhard, the Psocoptera collection of the Geneva Museum - a collection created by his own fieldwork and by his worldwide network of contacts depositing specimens is now of world importance. At the age of 60 Lienhard took early retirement in order to spend more time with his wife, who has multiple sclerosis.

Although Charles Lienhard has described many new taxa, his trademark attention to detail and encyclopaedic knowledge of the Psocoptera gave him a unique opportunity to make a more universal contribution by drawing together all the available information concerning a whole order of insects. His revision of the West Palaearctic species of Liposcelis included the first identification key that allows identification of all of the economically important species of this genus worldwide (Lienhard 1990). His book on the Psocoptera of the West Palaearctic, which appeared in the Faune de France series (Lienhard 1998), remains the standard work for identifying the psocids of this region and was awarded the A. Constant Prize by the French Entomological Society in 1998. The book is dedicated to André Badonnel, the eminent French Psocoptera specialist who acted as mentor from the beginning of Lienhard's study of the group and left his private collection of Psocoptera to the Geneva Museum on his death in 1991. Conscious that the huge number of genera and species that had been described in the second half of the $20^{\text {th }}$ century made an overview of the order difficult even for specialists, Lienhard suggested to his Australian colleague Courtney Smithers that they should produce an update to the world catalogue that he had published in 1967. The result of this successful collaboration (Lienhard and Smithers 2002) is a compilation of all information concerning the Psocoptera published up to the end of the $20^{\text {th }}$ century. Unlike most such catalogues, this work is not restricted to the taxonomic literature but includes all published works mentioning Psocoptera, and indicates for each species the bibliographic references concerning their geographic distribution, biology, ecology and, where relevant, economic importance. Since 2003 Lienhard has produced annual supplements to the catalogue and bibliography, which are published online in Psocid News. Checklists based on the catalogue for all countries, and a thematic bibliography of the Psocoptera literature published between 1688 and 2015 are available online at the Psocid News website. Many colleagues working on other groups have expressed envy and astonishment that the world's entire knowledge of the Psocoptera should be so easily accessible, and kept up to date. The Psocodea Species File Online database, managed by the Illinois Natural History Survey, was created from the catalogue and its updates. The dedication of the catalogue to his wife Heidi bears witness to the importance of her contribution to Lienhard's scientific work.

On his retirement in 2009, Lienhard was named honorary curator by the Geneva Museum, and he installed a small laboratory in his apartment where he continues his research on Psocoptera. Charles Lienhard is both modest and generous, a combination that has resulted in most of his scientific contacts developing into long-term collaborations during a harmonious career. His relationships with the Museum and with colleagues around the world have led to some particularly interesting projects in the years after his retirement.

The result he finds the most intriguing of his career is the discovery in a Brazilian cave of two specimens of Psyllipsocus yucatan with both surfaces of their wings covered by a thin, completely uniform layer of black microcrystals (Lienhard et al. 2012); an enigma for physics and biology! This study is one of Lienhard's numerous contributions to our knowledge of cave Psocoptera resulting from his many contacts amongst biospeleologists (including Bernd Hauser, Pierre Strinati, Villy Aellen, Philip Ashmole, Rodrigo Ferreira, Eugene Marais and Guiseppe Grafitti). He described the first blind (anophthalmus) psocid from a cave on the island of St Helena (Lienhard and Ashmole 1999, 2011). In the cave-dwelling genera Sensitibilla and Afrotrogla from southern Africa he discovered trichobothria not only on the tibia, for the first time in psocids, but also on the tarsi, something previously unknown in insects (Lienhard 2000, 2007). His study of the psocids of Brazilian caves collected by Rodrigo Ferreira led to the description of 15 new species of Psyllipsocus and the discovery of a new secondary genital organ found in the males of some species (Lienhard and Ferreira 2013, 2014, 2015). His discovery of the gynosome (the first female penis found in the animal kingdom) in the new cave-dwelling genus Neotrogla from Brazil (Lienhard et al. 2010) spawned a research team whose publication in Current Biology (Yoshizawa et al. 2014) was awarded the 2017 Ig Nobel Prize for biology. Despite the discovery making the headlines, Lienhard admits that the general interest it aroused, both in the scientific sphere and the wider world, surprised him. It is of particular satisfaction to him that a simple traditional study of morphological taxonomy revealed a phenomenon that currently exercises such fascination for evolutionary biologists.

Lienhard's collaboration with the brilliant young entomologist Kazunori Yoshizawa extends to many fields in addition to that which won the Ig Nobel, and includes the description of a remarkable fossil of a member of the family Archipsyllidae preserved in Cretaceous amber from Myanmar, which allowed them to define the new superorder Paracondylognatha within the Paraneoptera (Yoshizawa and Lienhard 2016). The only other palaeontological contribution Lienhard has made is a revision of the classification of the Psocoptera known from Cretaceous amber (Mockford et al. 2013), a study led by Edward Mockford, doyen of Psocopterists and considered by Lienhard as a shining example throughout his career. 


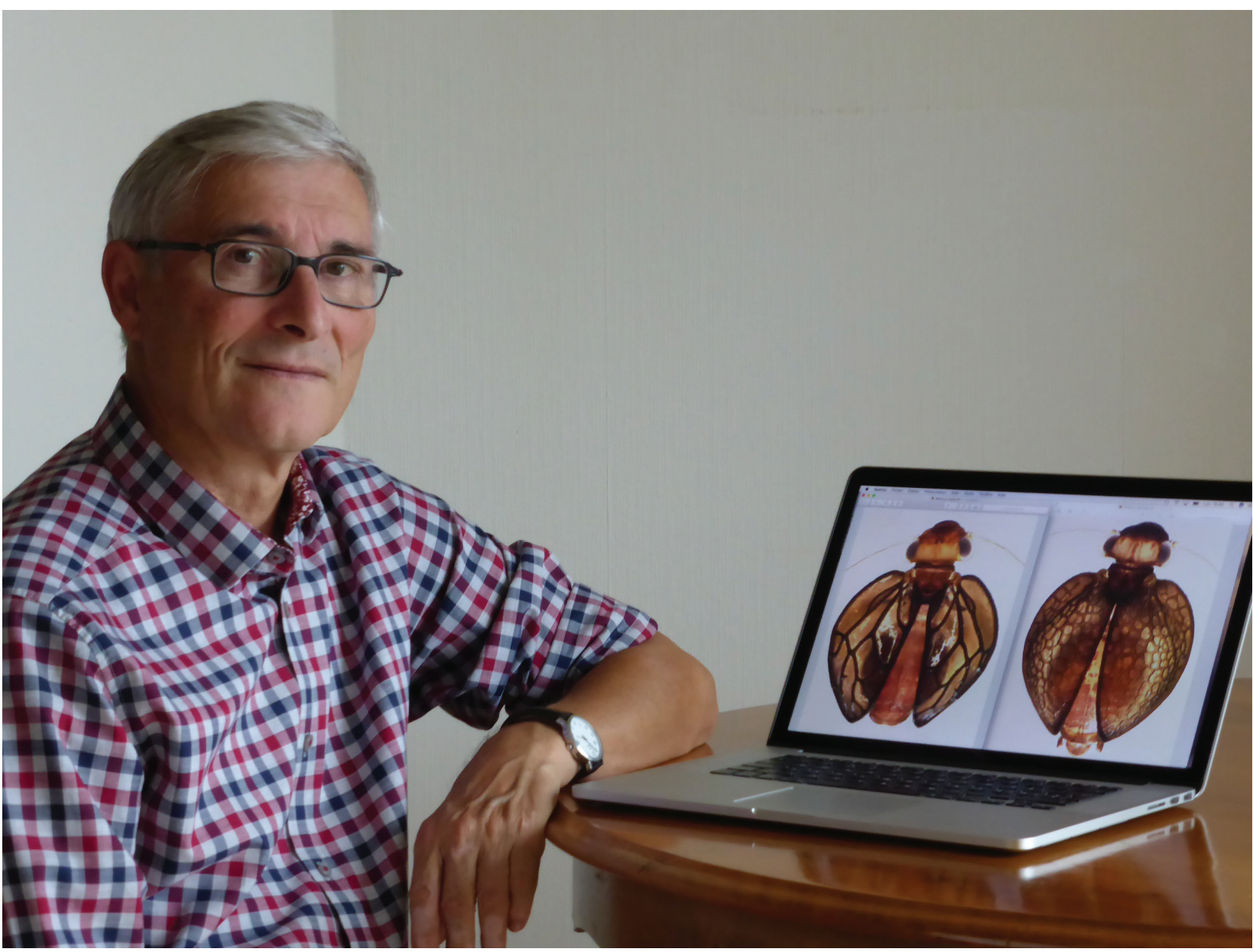

Charles Lienhard with images of Reticulopsocus besucheti (male left, female right), beetle-like protroctopsocid collected in Turkey by the Swiss coleopterist Claude Besuchet. (Photo: H. Lienhard, 2017).

Over the last few years Lienhard's two small grandchildren have revived his interest in watercolours and drawing, two pleasures long neglected in favour of scientific illustration. Asked which future projects are particularly dear to him, he replied provocatively, 'Inventing stories for children, and illustrating them with drawings and paintings, is less tedious and gives as much satisfaction as writing a scientific paper!' We hope nonetheless that Charles Lienhard will continue to dedicate part of his time to his beloved psocids.

\section{Acknowledgements}

We are grateful to Bernd Hauser for inspiring this article and numerous anecdotes. He and Anita Hollier commented on earlier versions the text.

\section{References}

Lienhard C (1990) Revision of the Western Palaearctic species of $L i$ poscelis Motschulsky (Psocoptera: Liposcelididae). Zoologische Jahrbücher (Abteilung Systematik) 117: 117-174.

Lienhard C (1998) Psocoptères euro-méditerranéens. Faune de France 83: XX-517.
Lienhard C (2000) A new genus of Prionoglarididae from a Namibian cave (Insecta: Psocoptera). Revue suisse de Zoologie 107(4): 871882. https://doi.org/10.5962/bhl.part.80152

Lienhard C (2007) Description of a new African genus and a new tribe of Speleketorinae (Psocodea: 'Psocoptera': Prionoglarididae). Revue suisse de Zoologie 114(3): 441-469. https://doi.org/10.5962/ bhl.part.80399

Lienhard C, Ashmole NP (1999) Sphaeropsocopsis myrtleae sp. n., a blind subterranean psocid from St Helena (Psocoptera: Sphaeropsocidae). Revue suisse de Zoologie 106(4): 905-912. https://doi. org/10.5962/bhl.part.80106

Lienhard C, Ashmole NP (2011) The Psocoptera (Insecta: Psocodea) of St Helena and Ascension Island (South Atlantic) with a new record from South Africa. Revue suisse de Zoologie 118(3): 423-449.

Lienhard C, Burckhardt D, Hauser B (1987) An improved beating tray and aspirator for collecting small arthropods. Mitteilungen der Schweizerischen Entomologischen Gesellschaft 60: 107-112.

Lienhard C, Ferreira RL (2013) Three new species of Psyllipsocus (Psocodea: 'Psocoptera': Psyllipsocidae) from Brazilian caves with description of a novel structure interpreted as a male accessory genital organ. Revue suisse de Zoologie 120(3): 421-443.

Lienhard C, Ferreira RL (2014) New species of Psyllipsocus from Brazilian caves (Psocodea: 'Psocoptera': Psyllipsocidae). Revue suisse de Zoologie 121(2): 211-246.

Lienhard C, Ferreira RL (2015) Review of Brazilian cave psocids of the families Psyllipsocidae and Prionoglarididae (Psocodea: 'Psocop- 
tera': Trogiomorpha) with a key to the South American species of these families. Revue suisse de Zoologie 122(1): 121-142.

Lienhard C, Ferreira RL, Gnos E, Hollier J, Eggenberger U, Piuz A (2012) Microcrystals coating the wing membranes of a living insect (Psocoptera: Psyllipsocidae) from a Brazilian cave. Scientific Reports 2: 408. https://doi.org/10.1038/srep00408

Lienhard C, Hollier J, Schwendinger P (2016) Dr Bernd Hauser, honorary curator at the Muséum d'histoire naturelle de Genève, is 80 . Mitteilungen der Schweizerischen Entomologischen Gesellschaft 89: 289-292.

Lienhard C, Oliveira Do Carmo T, Lopes Ferreira R (2010) A new genus of Sensitibillini from Brazilian caves (Psocodea: 'Psocoptera': Prionoglarididae). Revue suisse de Zoologie 117(4): 611-635. https:// doi.org/10.5962/bhl.part.117600

Lienhard C, Smithers CN (2002) Psocoptera (Insecta): World Catalogue and Bibliography. Instrumenta Biodiversitatis 5: xli-745.

Mockford EL, Lienhard C, Yoshizawa K (2013) Revised classification of 'Psocoptera' from Cretaceous amber, a reassessment of published information. Insecta Matsumurana, New Series 69: 1-26.

Yoshizawa K, Ferreira RL, Kamimura Y, Lienhard C (2014) Female penis, male vagina, and their correlated evolution in a cave in- sect. Current Biology 24(9): 1006-1010. https://doi.org/10.1016/j. cub.2014.03.022

Yoshizawa K, Lienhard C (2016) Bridging the gap between chewing and sucking in the hemipteroid insects: new insights from Cretaceous amber. Zootaxa 4079(2): 229-245. https://doi.org/10.11646/ zootaxa.4079.2.5

\section{Supplementary material 1}

\section{Liste des publications de Charles Lienhard}

Authors: Nico Schneider, John Hollier

Data type: bibliography

Copyright notice: This dataset is made available under the Open Database License (http://opendatacommons. org/licenses/odbl/1.0/). The Open Database License $(\mathrm{ODbL})$ is a license agreement intended to allow users to freely share, modify, and use this Dataset while maintaining this same freedom for others, provided that the original source and author(s) are credited. Link: https://doi.org/10.3897/alpento.2.30088.suppl1 